\title{
A difícil tarefa de definir quem é negro no Brasil
}

\author{
ENTREVISTA DE KABENGELE MUNANGA
}

$\mathrm{P}$

ARA O ANTROPÓLOGO Kabengele M unanga, professor-titular da Faculdade de Filosofia, L etras e C iências H umanas da U SP, não é fácil definir quem é negro no Brasil. Em entrevista concedida a ESTU D OS A VA CC ADOS, no último dia 13 de fevereiro, ele classifica a questão como "problemática", sobretudo quando se discutem políticas de ação afirmativa, como cotas para negros em universidades públicas. "C om os estudos da genética, por meio da biologia molecular, mostrando que muitos brasileiros aparentemente brancos trazem marcadores genéticos africanos, cada um pode se dizer um afro-descendente. Trata-se de uma decisão política", afirma.

Kabengele M unanga é atualmente vice-diretor do Centro de Estudos Africanos e do M useu de Arte C ontemporânea da U SP.

$\mathrm{N}$ asceu em 19 de novembro de 1942 no antigo Zaire, onderecebeu sua educação primária e secundária. Sua educação superior ocorreu em seu país natal, de 1964 a 1969. Foi o primeiro antropólogo formado na então U niversité O fficielle du Congo, em Ciências Sociais (Antropologia Social e Cultural).

No mesmo ano em que se graduou, recebeu uma bolsa do governo belga, como pesquisador no M useu Real da África Central, em Tervuren e como aluno do programa de pós-graduação na U niversidade Católica de Louvain, na Bélgica. Essa bolsa foi interrompida em 1971, por questões políticas, antes da conclusão de seu doutorado.

Em julho de 1975, veio ao
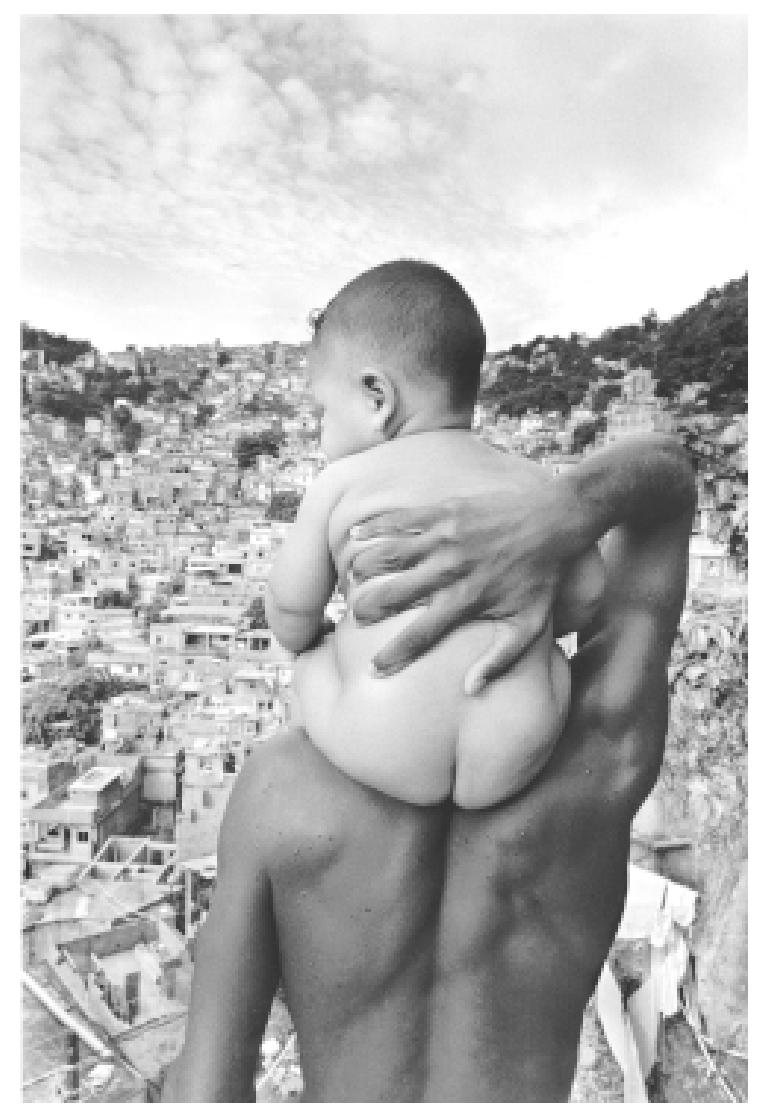

A ndréC ypriano. Pai e filho, Rio de Janeiro, 1999. Fotografia P/B, C ol eção particular.

Brasil com uma bolsa da U SP, a fim 
de continuar seus estudos. D efendeu sua tese em 1977. N o mesmo ano, voltou a seu país, mas não conseguiu permanecer lá por muito tempo. Regressou ao B rasil em 1979, para trabal har na U niversidade Federal do R io Grande do N orte. Em 1980, iniciou a segunda fase de sua carreira na U SP. Em 2002, o governo brasileiro concedeu a Kabengele $M$ unanga o diploma de sua admissão na $O$ rdem do M érito Cultural, na classe de Comendador.

Participaram da entrevista com Kabengele M unanga, o editor de ESTUDOS A VAN ÇAD OS, professor Alfredo Bosi, e o editor assistente, jornalista D ario L uis Borelli.

Estud os A vançados - Q uem énegro no Brasil?É um problema de identidade ou de denominação?

Kabengele Munanga - Parece simples definir quem é negro no Brasil. M as, num país que desenvolveu o desejo de branqueamento, não é fácil apresentar uma definição de quem é negro ou não. $\mathrm{H}$ á pessoas negras que introjetaram 0 ideal de branqueamento e não se consideram como negras. Assim, a questão da identidade do negro é um processo doloroso. O s conceitos de negro e de branco têm um fundamento etno-semântico, político e ideológico, mas não um conteúdo biológico. Politicamente, os que atuam nos movimentos negros organizados qualificam como negra qualquer pessoa que tenha essa aparência. É uma qualificação política que se aproxima da definição norte-americana. N os EU A não existe pardo, mulato ou mestiço e qualquer descendente de negro pode simplesmente se apresentar como negro. Portanto, por mais que tenha uma aparência de branco, a pessoa pode se declarar como negro.

No contexto atual, no Brasil a questão é problemática, porque, quando se colocam em foco políticas de ações afirmativas - cotas, por exemplo - , o conceito de negro torna-se complexo. Entra em jogo também o conceito de afro-descendente, forjado pelos próprios negros na busca da unidade com os mestiços.

Com os estudos da genética, por meio da biologia molecular, mostrando que muitos brasileiros aparentemente brancos trazem marcadores genéticos africanos, cada um pode se dizer um afro-descendente. Trata-se de uma decisão política.

Se um garoto, aparentemente branco, declara-se como negro e reivindicar seus direitos, num caso relacionado com as cotas, não há como contestar. 0 único jeito é submeter essa pessoa a um teste de DNA. Porém, isso não é aconselhável, porque, seguindo por tal caminho, todos os brasileiros deverão fazer testes. E o mesmo sucederia com afro-descendentes que têm marcadores genéticos europeus, porque muitos de nossos mestiços são euro-descendentes.

\section{0 problema das cotas}

E STU D os A VA CÇAD os - Em face da concessão de cotas para negros, ou para outros segmentos da população que não tiveram a mesma condição de cursar escolas da classe média ou alta, qual a sua posição? 
K abengele Munanga - Por ocasião dostrezentos anos da morte de Zumbi dos Palmares, em 1995, começamos a discutir essa questão na U SP, numa comissão criada pela reitoria.

O s movimentos negros, principalmente o N úcleo da Consciência N egra, pleitearam o estabelecimento de cotas em nossa universidade. Contudo, afirmei que não poderíamos discutir o sistema de cotas sem antes fazer uma pesquisa preliminar em países que já têm experiência de cotas, como os EU A, o C anadá, a Austrália ou a Índia.

N aquela ocasião, apresentei essa proposta, mas ela não foi levada adiante. No entanto, na base de um levantamento do Instituto de Pesquisa Econômica Aplicada (IPEA), um órgão do governo federal, conclui-se que realmente há uma grande defasagem na escolaridade dos negros nas universidades brasileiras.

I nfelizmente, porém, começamos a enfrentar a questão pelas cotas, a partir da decisão do governador Anthony Garotinho, do Rio de J aneiro, que provocou uma confusão muito grande, quando estabeleceu cotas nas universidades estaduais. N o entanto, mesmo num país com tantas desigualdades, as políticas universalistas não resolvem o problema do negro. Para isso precisamos formular políticas específicas contra as desigualdades, mas o caminho não deve ser necessariamente por meio de cotas.

Essa discussão, todavia, é importante, porque antes nem se tocava no assunto. E scutei outro dia algo muito positivo quando alguém dizia que deveria haver cotas para pobres. O ra, antes ninguém apresentou esse ponto de vista. 0 que mais me surpreende é que jamais o movimento negro se disse contrário a cotas para brancos pobres.

A questão ainda está mal discutida, sendo formulada num tom passional, tanto pelos negros como pelos intelectuais. A questão não é a existência ou não das cotas. $O$ fundamental é aumentar o contingente negro no ensino superior de boa qualidade, descobrindo os caminhos para que isso aconteça.

Para mim, as cotas são uma medida transitória, para acelerar o processo. $\mathrm{N}$ o entanto, julgo que não somente os negros, mas também os brancos pobres têm o direito às cotas. Se as cotas forem adotadas, devem ser cruzados critérios econômicos com critérios étnicos. Porque meus filhos não precisam de cotas, assim como outros negros da classe média.

Estudos A vançados - O sr. iniciou suas declarações dando uma opinião contra as cotas, mas agora aponta para o problema da urgência. As cotas aparecem como uma medida de urgência?

Kabengele Munanga - Sim. Ao menos que o país diga que tem hoje uma outra proposta emergencial melhor, que não abra mão de uma política universalista com vistas ao aperfeiçoamento do nível do ensino básico. É bom lembrar que a escola pública já apresentou melhor qualidade, mas o negro e o pobre não entravam nela. 


\section{Melhorar a escola pública}

ESTUd os A vançAD os - O sr. acha que a médio prazo a alternativa seria uma transformação mais profunda do ensino básico e secundário? U m número considerável de alunos negros faz o segundo grau em escolas públicas. $\mathrm{N}$ ão falo deles como negros, mas sim como pobres. Será que as cotas não resolvem 0 problema porque o enfrentam no fim da linha, em vez de atacá-lo no começo?

K abengeleM unanga - Sim. Porém, vivo aqui há28 anose desde que cheguei escuto esse discurso. M as nunca vi luta política e social alguma para a melhoria da escola pública. Só há o discurso. M as o que fazer com a vítima? Esperar que isso aconteça por milagre, ou pressionar a sociedade através de uma proposta: como pelo menos cuidar da escola pública?

A dúvida que tenho é a seguinte: num país onde a privatização do ensino é cada vez maior e no qual o lobby das escolas particulares é tão forte, só posso antever uma melhoria a longo prazo. Lembro-me de que o primeiro processo contra as propostas de cotas no Rio de Janeiro veio do sindicato das escolas privadas.

D evido a essa tendência para a privatização das escolas públicas, não acredito numa rápida melhoria delas. A desigualdade social que existe há quatrocentos anos não pode ser resolvida por meio de políticas universalistas. É preciso, portanto, traçar políticas específicas para se encontrar uma solução.

\section{A discriminação racial}

A palavra "social" incomoda-me muito. Q uando dizem que a questão do negro é uma questão social, o que quer dizer "social" ? As relações de gênero são uma questão social; a discriminação contra o portador de deficiência é uma questão social; a discriminação contra o negro é uma questão social. O ra, o social tem nome e endereço. $\mathrm{N}$ ão podemos diluir, retirar o nome, a religião e o sexo e aplicar uma solução química. 0 problema social tem de ser atacado especificamente.

A discriminação racial precisa ser urgentemente enfrentada. $\mathrm{N}$ ós, negros, também temos problemas de alienação de nossa personal idade. M uitas vezes trabal hamos o problema na ponta do iceberg que é visível. M as a base desse iceberg deixa de ser trabalhada.

E stou aqui, como disse, há 28 anos. Vou a restaurantes utilizados pela classe média e a centros de alimentação nos shoppings. Encontro famílias brancas comendo (homem, mulher e filhos), mas dificilmente estão ali famílias negras. Há uma classe média negra, mas que se auto discrimina e que é também discriminada. D esafio vocês a me dizerem que encontraram quatro famílias negras em cinco restaurantes de classe média em São Paulo. Vejamoso meu caso: em meu segundo casamento (que é interracial) percebia aquelas "olhadas" - mulher branca, filhos negros do primeiro casamento e filhos mestiços do segundo. Ninguém me expulsava desses lugares, mas eu via as "olhadas" ... 


\section{As pesquisas na U niversidade de São Paulo}

E STU D os A van çA D os - A U SP está completando setenta anos e gostaria que o sr. falasse sobre as principais linhas de pesquisa so bre gênero e raça na Faculdade de Filosofia, Letras e Ciências H umanas.

K abengele Munanga - Até onde eu saiba não há uma linha de pesquisa sobre gênero e raça. $\mathrm{H}$ á um núcleo de estudo da mulher, dirigido pela professora E va Blay. D e vez em quando ela convida al guma jovem pesquisadora negra. Talvez exista uma explicação histórica para isso, porque normalmente quem estuda esse tema são as mulheres. $M$ as, não temos professoras negras de sociologia ou de antropologia na U niversidade de São Paulo. Entrei nela em 1980, como professor, e nunca mais houve um outro professor negro no D epartamento. L embro-me do dia em que Florestan Fernandes recebeu o título de professor emérito e eu estava na fila para cumprimentá-lo. Eu não sabia que ele me conhecia. Por isso assusteime quando ele me disse que estava muito contente com a minha presença naquela solenidade. Pois fora informado de que ali estava um negro que nem era brasileiro.

\section{U $\mathbf{m}$ antropólogo em dois mundos}

ESTUD OS A vANÇAD os - O sr. poderia descrever um pouco sua trajetória até chegar no Brasil?

KabengeleMunanga - $\mathrm{N}$ asci no antigo Zaire, que hoje se chama R epública Democrática do Congo, numa aldeia no centro do país. Estudei num colégio interno de jesuítas e fiz graduação em Antropologia. Aliás, fui o primeiro antropólogo formado naquela universidade e o único aluno que teve aulas com professores franceses, belgas e americanos convidados, pois não havia ainda professores africanos na U niversidade quando eu entrei Lá, nós acabávamosa graduação com um tipo de dissertação que se chamava $M$ émoire. 0 sistema belga dava 0 direito de se entrar diretamente no doutorado. Em razão disso, comecei 0 doutorado em Louvain, na Bélgica, em 1969. Dois anos depois, voltei para pesquisas de campo. M as houve complicações políticas. Cortaram a bolsa e não pude fazer mais nada.

Por coincidência, encontrei no Congo, em 1973, o professor Fernando M ourão, que ali estava realizando palestras sobre as contribuições africanas para a cultura brasileira. Conversamos e ele me disse que a U SP possuía um projeto de cooperação com as universidades africanas e que nela eu poderia completar 0 doutorado. Cheguei aqui em 1975 e me inscrevi no doutorado, sob a orientação do professor J oão Batista Borges Pereira. Como eu estava bastante adiantado, em dois anos defendi minha tese. Trabalhei sobre o processo de mudanças socioeconômicas numa comunidade no sul do Congo. Voltei correndo à militância para colocar meus conhecimentos à disposição de meu país. M as quando cheguei lá, tive de fugir para o Brasil.

Q uando houve a independência do meu país, o antigo Zaire (em 30 de junho de 1960), eu estava com dezoito anos. A Faculdade foi criada pela Bélgica, 
seis anos antes da independência, em conseqüência de pressões internacionais. Fui alfabetizado na minha língua materna, mas no fim do primeiro grau começou 0 ensino em francês. 0 resto do curso foi em francês. I sso porque, com mais de duzentas línguas, não era possível escolher uma para ser a língua nacional. Todos os alfabetizados falam francês.

E stud os A vançad os - Alguma dessas línguas africanas é hegemônica?

K abengel eMunanga - $O$ suahili que é uma língua falada em muitos países africanos, em parte do Zaire, Tanzânia, Burundi, Q uênia e U ganda.

E STUd os A van ÇAD os - Suahili tem alguma coisa a ver com o árabe?

Kabengele Munanga - Cerca de vinte por cento do vocabulário, porque desde a Antigüidade os árabes tiveram muita influência no continente, a partir do oceano Índico, além de terem sido responsáveis pelo tráfico oriental e transaariano (entre os anos de600-1600). M as a estrutura da língua é totalmente bantu (africana).

ESTUd os Avançad os - M uito obrigado. 